\title{
KARAKTERISASI SOSIAL EKONOMI DAN RESPON MASYARAKAT TERHADAP PENGEMBANGAN KARET DI HUTAN PRODUKSI JAWA BARAT
}

\author{
Socio-Economic Characteristics and Community Response to the Development \\ of Rubber Plantation in Production Forest West Java \\ Titik WIDYASARI \\ Balai Penelitian Getas, Pusat Penelitian Karet \\ Jl. Pattimura KM 6 Salatiga Jawa Tengah \\ Email: titikwidyasari@gmail.com
}

Diterima : 23 Februari 2016 / Direvisi : 1 Juli 2016 / Disetujui : 22 Juli 2016

\begin{abstract}
Indonesia has opportunity to be the biggest rubber producer in the world due to the availability of land and labour to support the development of rubber plantation. One of those opportunities is production forest that was managed by the state. In a rubber plantation development planning, it is very important to analyze of socio-economic of surrounding communities, so the sustainability of the development of rubber plantation can run smoothly and minimize conflict with the public interest community institutions around the production forest. the aim of this article was to give information about socio-economic community surrounding the production forest that would be developed into rubber plantation. this research used survey method and choose sample by purposive that held in four regencies bordering the production forest which managed by Company A which would be developed to be rubber plantation in West java Province, i.e Sumedang, Majalengka, Purwakarta, and Indramayu. At village rubber, data was collected by Focus Group Discussion (FGD) method that involving community around the forest, administrators forest village community agencies, and villages officials. Data was analyzed with descriptive method.The result showed that the infrastructure and institutional at four districts has commonly been proper. the land use and vegetation at production forest were teak, Eucalyptus, Mahogany, Gmelina, intercropping, cattle and buffalo. 90-95\% population was local residents that 47\%-90\% of theire livehood was from agricultureas farmer- labor developed to be rubber plantation, in general respondets agree but it was needed to reexamined the concept of
\end{abstract}

Community Based Forest Managemet (CBFM) that was already running.

Keywords: Rubber; Socio-economic characteristics; production forest; $C B F M$

\section{Abstrak}

Indonesia berpeluang menjadi produsen karet terbesar dunia karena masih tersedianya lahan dan tenaga kerja yang mendukung pembangunan kebun karet. Salah satu peluang tersedianya lahan adalah hutan produksi yang dikelola oleh negara. Dalam perencanaan pembangunan kebun karet sangat penting dilakukan analisis dari sisi sosial ekonomi masyarakat sekitar, sehingga keberlangsungan pembangunan kebun karet dapat berjalan dengan lancar dan meminimalisir konflik kepentingan masyarakat dengan lembaga masyarakat sekitar hutan produksi. Tujuan penulisan artikel ini adalah menyajikan informasi mengenai kondisi sosial masyarakat sekitar hutan produksi yang akan dikembangkan menjadi kebun karet. Penelitian dilakukan menggunakan metode survei dan memilih sampel secara purposive yang dilakukan di empat kabupaten yang berbatasan dengan hutan produksi yang dikelola oleh Perusahaan A yang akan dikembangkan menjadi kebun karet di Provinsi Jawa Barat, yaitu Kabupaten Sumedang, Majalengka, Purwakarta dan Indramayu. Di tingkat desa, pengambilan data menggunakan metode Focus Group Discussion (FGD) yang melibatkan masyarakat sekitar hutan, pengurus Lembaga Masyarakat Desa Hutan (LMDH), dan perangkat desa. Data dianalisis 
menggunakan metode diskriptif. Hasil penelitian menunjukkan pada umumnya infrastruktur dan kelembagaan di keempat kabupaten sudah memadai. Adapun land use dan vegetasi di hutan produksi berupa tanaman Jati, Kayu Putih, Mahoni dan Gmelina, tanaman tumpangsari serta ternak sapi dan kerbau. Sejumlah 90\%-95\% penduduk merupakan penduduk lokal, dengan mata pencaharian 47\%-90\% di bidang pertanian sebagai petani-buruh tani dan belum memahami teknik budidaya tanaman karet. Jika sebagian hutan produksi diubah menjadi perkebunan karet, pada umumnya memiliki respon setuju namun perlu meninjau ulang konsep Pengelolaan Hutan Bersama Masyarakat (PHBM) yang sudah berjalan.

Kata kunci: Karet; karakterisasi sosial ekonomi; hutan produksi; PHBM.

\section{PENDAHULUAN}

Konsumsi karet alam sebagian besar dilakukan oleh negara-negara industri maju dan negara produsen karet alam sendiri.
Pada tahun 2014, jumlah konsumsi karet alam dunia mencapai 11,86 juta ton. Negara-negara konsumen utama karet alam dunia adalah China, India, Jepang, dan negara-negara produsen karet alam sendiri (Tabel 1). Pusat "grafitasi" konsumsi karet alam dunia pada saat ini berada di Asia, karena lebih dari 71\% konsumsi karet alam dilakukan oleh negara-negara Asia.

Komoditas perkebunan menjadi andalan bagi pendapatan nasional dan devisa negara Indonesia, yang nilai ekspornya pada tahun 2013 mencapai USD 29.476 milyar atau setara dengan IDR 353.713 trilyun (asumsi 1 USD = Rp 12.000). Karet merupakan komoditas ekspor yang cukup besar bagi Indonesia, pada tahun 2013 ekspor karet alam mengalami kenaikan menjadi 2,70 juta ton dengan nilai ekspor sebesar USD 6.906,95 juta, dan pada tahun 2014 volume ekspor karet alam mengalami penurunan 2,91\% menjadi 2,6 juta ton dengan nilai USD 4.741,49 juta (Badan Pusat Statistik [BPS], 2014).

Indonesia memiliki peluang untuk menjadi produsen karet terbesar dunia dengan memiliki keunggulan komparatif

Tabel 1. Konsumsi karet alam dunia berdasarkan negara, 2014

Table 1. The world's natural rubber consumption by country, 2014

\begin{tabular}{lcr}
\hline & \multicolumn{2}{c}{$\begin{array}{c}\text { Konsumsi karet alam dunia } \\
\text { Natural rubber consumption }\end{array}$} \\
\cline { 2 - 4 } \multicolumn{1}{c}{ Country } & $\begin{array}{c}\text { Jumlah } \\
\text { Value } \\
\text { (OoO ton) }\end{array}$ & $\begin{array}{c}\text { Persentase } \\
\text { Percentage } \\
(\%)\end{array}$ \\
\hline China & $4.510,00$ & 38,04 \\
India & $1.012,20$ & 8,54 \\
Jepang & 709,00 & 5,98 \\
Thailand & 538,10 & 4,54 \\
Indonesia & 525,40 & 4,43 \\
Malaysia & 447,40 & 3,77 \\
Korea & 402,10 & 3,39 \\
Eropa & $1.117,90$ & 9,43 \\
Amerika & $1.700,10$ & 14,34 \\
Australia dan Afrika & 892,80 & 7,53 \\
$\quad$ Jumlah & $11.855,00$ & 100,00 \\
\hline
\end{tabular}

Sumber (Source): International Rubber Study Group [IRSG], 2015 
dan kompetitif yang lebih baik dibandingkan dengan negara pesaing lainnya seperti Thailand dan Malaysia, karena masih tersedianya lahan dan tenaga kerja yang mendukung pembangunan kebun karet (Syarifa, 2014). Pada tahun 2014 areal perkebunan karet di Indonesia telah mencapai luasan 3,61 juta $\mathrm{Ha}$, dimana \pm $85 \%$ dari total luasan merupakan karet rakyat (Badan Pusat Statistik [BPS], 2015). Salah satu peluang tersedianya lahan untuk pengembangan karet adalah hutan produksi yang dikelola oleh negara.

Menurut Peraturan Pemerintah Republik Indonesia Nomor 10 Tahun 2010, tentang tata cara perubahan peruntukan dan fungsi kawasan hutan, pengertian hutan produksi adalah kawasan hutan yang mempunyai fungsi pokok memproduksi hasil hutan. Hutan produksi dibagi menjadi tiga golongan, yaitu (1) hutan produksi tetap, (2) hutan produksi terbatas, dan (3) hutan produksi yang dapat dikonversi. Hutan produksi yang dapat dikonversi merupakan kawasan hutan yang secara ruang dicadangkan untuk digunakan bagi pembangunan di luar kegiatan kehutanan.

Tanaman karet (Hevea brasiliensis Muell Arg) merupakan komoditi hasil hutan bukan kayu yang termasuk dalam kelompok tanaman penghasil getah yang dapat diusahakan di kawasan hutan (Lampiran Peraturan Menteri Kehutanan Nomor : P.35/Menhut-II/2007). Namun demikian, selain menghasilkan getah, tanaman karet juga dapat menghasilkan kayu.

Karet memiliki sifat-sifat yang umumnya dimiliki oleh jenis tanaman hutan lainnya, baik dari sisi ekonomi maupun ekologi sebagai berikut : (1) Tanaman karet sebagai penghasil kayu, (2) Tanaman karet sebagai penambat karbon, (3) Tanaman karet sebagai tanaman konservasi (Nugroho, 2012). Nugroho (2012) juga menyebutkan bahwa menurut kajian Indonesian Sawn Timber and Woodworking Association (ISWA) seluruh bagian tanaman karet dapat dimanfaatkan. Tunggul dan cabang akar $(15 \%)$ dapat dijadikan arang dan papan partikel, batang bekas sadapan (15-20\%) dapat dijadikan papan gypsum dan parquet (flooring), batang bekas sadapan (20-25\%) untuk furnitur, kayu lapis dan kayu rekonstruksi (Laminated Veneer
Lumber/LVL) dan batang di atas batang sadapan (10-15\%) dapat dijadikan kayu olahan. Selain itu, cabang utama dan kedua bisa menghasilkan produk kerajinan tangan, mainan serta papan serat. Ranting dan daun dapat dikomposkan atau dijadikan arang (Kaban, 2009). Chantuma, Kunarasiri, dan Chantuma (2012) juga melaporkan bahwa setiap satu pohon karet yang berumur 25 tahun menghasilkan hingga $822,4 \mathrm{Kg}$ biomassa dengan kandungan karbon mencapai 44,52\%.

Pembangunan kehutanan menurut Arief (2001) merupakan upaya pengelolaan sumber daya hutan secara lestari dan pemanfaatan hutan sebesar-besarnya untuk kemakmuran rakyat. Sedangkan pengelolaan hutan merupakan aplikasi teknik pengusahaan dan prinsip-prinsip $\mathrm{t}$ e $\mathrm{kn} \mathrm{i} \mathrm{k} \mathrm{k} \mathrm{e} \mathrm{h} \mathrm{u} \mathrm{t} \mathrm{n} \mathrm{a} \mathrm{n} \mathrm{u} \mathrm{n} \mathrm{t} \mathrm{u} \mathrm{k}$ mengoperasionalkan sifat-sifat hutan (Simon, 1993). Paradigma baru dalam pembangunan kehutanan adalah pembangunan yang berkelanjutan, dimana pembangunan kehutanan harus berdasarkan pendekatan intra generasi dan inter generasi. Menurut Muschett (1977) komponen pembangunan kehutanan yang berkelanjutan harus memenuhi tiga komponen, yaitu ekologi, sosial budaya dan ekonomi. Pembangunan kehutanan terus berlangsung meskipun sebagian lahan ada yang dikonversi menjadi karet.

Pengelolaan hutan yang dilakukan oleh Perusahaan A sebagai pengelola hutan produksi di Jawa Barat dan Banten mengalami redesain sejak tahun 2012. Langkah tersebut dilakukan untuk mengakomodasi kepentingan kawasan lindung, kepentingan bisnis keamanan lingkungan, serta ekonomi masyarakat desa hutan sekitarnya. Saat ini bisnis Perusahaan A telah dikembangkan lebih luas yaitu albasia atau sengon, karet, wisata hutan, dan lainnya. Perkembangan disesuaikan dengan kondisi alam Jawa Barat, dan menyeimbangkan aspek kepentingan aspek lingkungan, dimana pendapatan bisnis dari jasa lain digunakan untuk mensubsidi hutan-hutan lindung. Keseimbangan dijaga dengan menyeimbangkan aspek umum dari perlindungan hutan dan alam, serta kepentingan bisnis untuk dirinya sendiri. Pada periode tahun 2012-2025 dibangun 
perkebunan karet seluas \pm 10.369 Ha secara bertahap di beberapa wilayah hutan produksi di Jawa Barat. Pembangunan kebun karet disesuaikan dengan kondisi agroekosistemnya, terutama topografi datarbergelombang dan asal vegetasi hutan kayu. Kelas kesesuaian lahan untuk tanaman karet diidentifikasi sebagai kelas S2 (Sesuai). Kelas kesesuaian lahan ini akan mempengaruhi produktivitas karet atau lateksnya. Hasil analisis finansial pada lahan tersebut dinilai layak, dengan ketentuan nilai NPV $>0, \mathrm{~B} / \mathrm{C}>1$ dan IRR $>$ suku bunga yang berlaku. Pada saat produksi karet turun hingga 15\%, harga karet turun hingga $14,6 \%$, harga sarana produksi pupuk naik $125 \%$, dan upah tenaga kerja naik hingga $84 \%$, usaha perkebunan karet secara finansial masih layak untuk dilaksanakan (Pusat Penelitian Karet [Puslit Karet], 2015).

Suatu perencanaan pembangunan kebun karet tidak hanya dilihat dari sisi ekonomi dan tanah saja, namun juga sangat penting dilakukan analisis dari sisi sosial masyarakat sekitar, sehingga keberlangsungan pembangunan kebun karet dapat berjalan dengan lancar dan meminimalisir konflik dengan kepentingan masyarakat dan lembaga masyarakat sekitar hutan produksi. Tujuan dari penulisan artikel ini adalah menyajikan informasi mengenai kondisi sosial masyarakat sekitar hutan produksi yang akan dikembangkan menjadi kebun karet.

\section{BAHAN DAN METODE}

Penelitian dilakukan menggunakan metode survei dan memilih sampel secara purposive yang dilakukan di empat kabupaten yang berbatasan dengan hutan produksi yang dikelola oleh Perusahaan A yang akan dikembangkan menjadi kebun karet di Provinsi Jawa Barat, yaitu Kabupaten Sumedang, Majalengka, Purwakarta dan Indramayu. Di tingkat desa, pengambilan data menggunakan metode Focus Group Discussion (FGD) yang melibatkan masyarakat sekitar hutan, pengurus Lembaga Masyarakat Desa Hutan (LMDH), dan perangkat desa. Survei dilakukan di empat Kabupaten, tujuh Kecamatan dan 11 Desa. Responden berjumlah 47 orang, yang terdiri dari 28 orang masyarakat sekitar hutan dan pesanggem, 10 orang pengurus LMDH, dan 9 orang perangkat desa seperti tertera dalam Tabel 2. Data dianalisis menggunakan metode diskriptif.

Tabel 2. Jumlah responden yang disurvei di sekitar hutan produksi

Table 2. Number of respondents were surveyed at around the production forest

\begin{tabular}{|c|c|c|c|c|c|}
\hline \multirow[b]{2}{*}{$\begin{array}{c}\text { Kabupaten } \\
\text { District }\end{array}$} & \multirow[b]{2}{*}{$\begin{array}{l}\text { Kecamatan } \\
\text { Sub-District }\end{array}$} & \multirow[b]{2}{*}{$\begin{array}{c}\text { Desa } \\
\text { Villages }\end{array}$} & \multicolumn{3}{|c|}{$\begin{array}{l}\text { Sampel (orang) } \\
\text { Sample (person) }\end{array}$} \\
\hline & & & $\begin{array}{c}\text { Perangkat } \\
\text { Desa } \\
\text { Village } \\
\text { Officials }\end{array}$ & $\begin{array}{c}\text { Pengurus } \\
\text { LMDH } \\
\text { Forest } \\
\text { Village } \\
\text { Community } \\
\text { Association } \\
\text { Official }\end{array}$ & $\begin{array}{c}\text { Masyarakat } \\
\text { di sekitar } \\
\text { hutan dan } \\
\text { pesanggem } \\
\text { Community } \\
\text { at around } \\
\text { the forest }\end{array}$ \\
\hline \multirow{5}{*}{ Sumedang } & \multirow{2}{*}{ Tomo } & Tomo & 1 & 1 & 2 \\
\hline & & Karyamukti & 1 & 1 & 4 \\
\hline & \multirow{3}{*}{ Ujung Jaya } & Bugel & 0 & 1 & 2 \\
\hline & & Ujung Jaya & 1 & 1 & 4 \\
\hline & & Sakur Jaya & 1 & 1 & 3 \\
\hline Majalengka & Kertajati & Mekarmulya & 1 & 1 & 2 \\
\hline \multirow[t]{2}{*}{ Purwakarta } & Kiarapedes & Margaluyu & 1 & 1 & 2 \\
\hline & Cibatu & Wanawali & 0 & 0 & 5 \\
\hline \multirow[t]{4}{*}{ Indramayu } & Terisi & Cikawung & 1 & 1 & 2 \\
\hline & Gantar & Mekarwaru & 1 & 1 & 0 \\
\hline & & Sanca & 1 & 1 & 2 \\
\hline & Jumlah (Total) & & 9 & 10 & 28 \\
\hline
\end{tabular}

Sumber : data primer

Source : primary data 
Data karakteristik sosial ekonomi antara lain: (1) kondisi umum kabupaten, (2) data demografi; (3) ketersediaan tenaga kerja di Kabupaten; (4) pengetahuan responden terhadap budidaya tanaman karet dan (5) respon masyarakat setempat terhadap rencana pembangunan kebun karet di areal tanaman yang sudah ada.

\section{HASIL DAN PEMBAHASAN}

\section{Kondisi Umum Wilayah}

Provinsi Jawa Barat memiliki luas wilayah daratan 3.710.061,32 $\mathrm{Ha}$, yang secara administratif terdiri dari 27 kabupaten/kota, meliputi 18 kabupaten dan 9 kota, sedangkan jumlah kecamatan 626, daerah perkotaan 2.671 dan 3.291 perdesaan (BPS, 2015).

Dalam penelitian ini, survei dilakukan pada hutan produksi yang berada di empat kabupaten, yaitu Kabupaten Sumedang, Majalengka, Purwakarta dan Indramayu. Berikut profil masing-masing kabupaten: a. Kabupaten Sumedang

Kabupaten Sumedang memiliki luas wilayah 152.220 Ha yang terdiri dari 26 kecamatan dengan 272 desa dan 7 kelurahan.

b. Kabupaten Majalengka

Luas daerah Kabupaten Majalengka adalah $1.204,24 \mathrm{~km}^{2}$ atau sekitar 2,71\% dari luas Provinsi Jawa Barat. Secara geografis, Kabupaten Majalengka terletak di bagian timur Provinsi Jawa Barat.

c. Kabupaten Purwakarta

Luas wilayah Kabupaten Purwakarta tercatat $971,72 \mathrm{~km}^{2}$ atau sekitar 2,81\% dari luas wilayah Provinsi Jawa Barat. Sejak Januari 2001, Kabupaten Purwakarta mempunyai 17 kecamatan dengan 192 desa/kelurahan (183 desa dan 9 kelurahan). Kabupaten Purwakarta berada pada titik-temu tiga jalur utama lalu-lintas yang sangat strategis, yaitu jalur Purwakarta-Jakarta, PurwakartaBandung dan Purwakarta-Cirebon yang merupakan jalur utama ke wilayah Jawa Tengah.

d. Kabupaten Indramayu

Kabupaten Indramayu terletak di pesisir utara Pulau Jawa dan memiliki 10 kecamatan dengan 35 desa yang

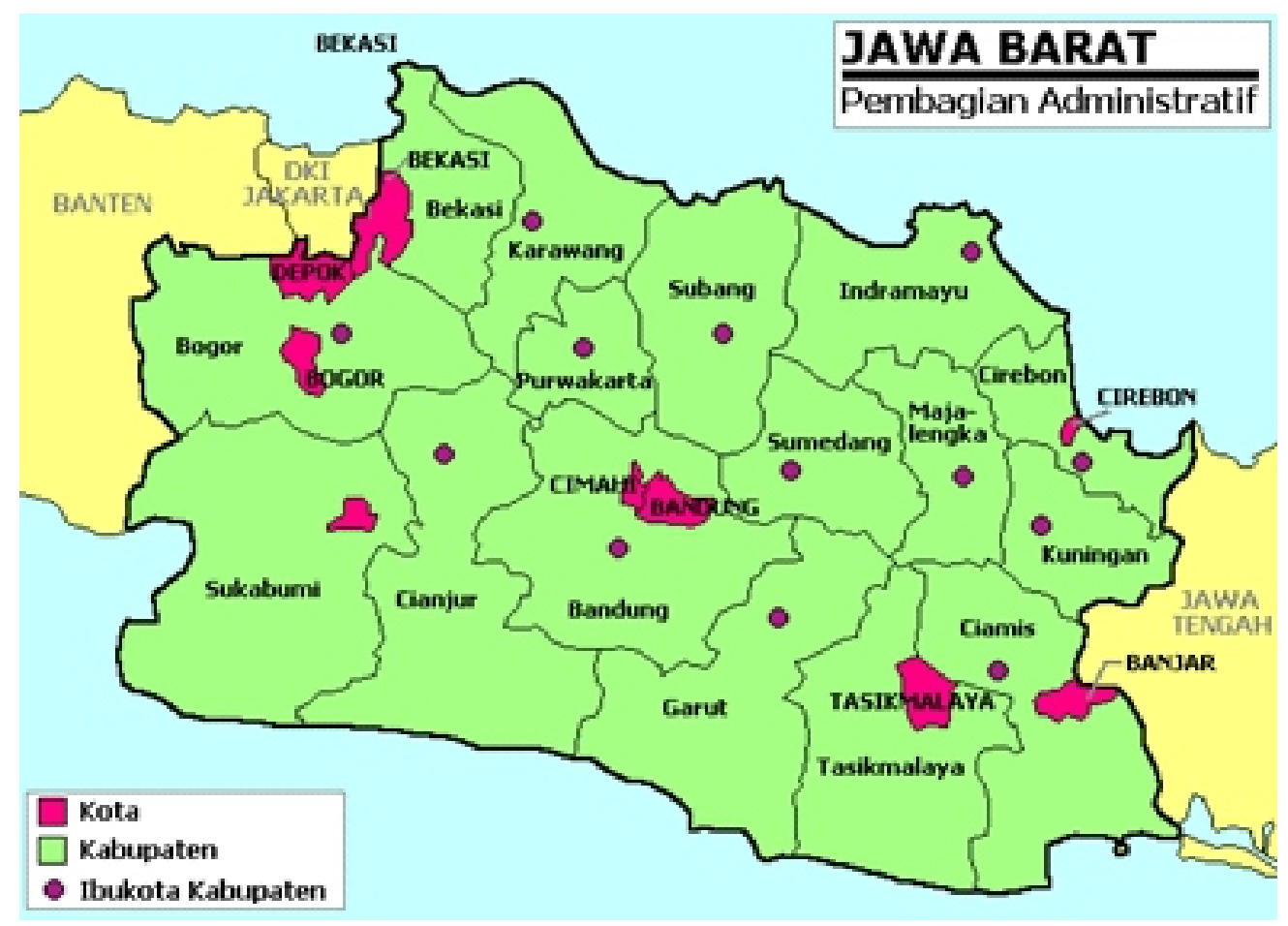

Gambar 1. Peta Provinsi Jawa Barat Figure 1. Map of West Java Province 
berbatasan langsung dengan laut Jawa dengan panjang garis pantai $114,1 \mathrm{Km}$. Luas wilayah Indramayu yang tercatat seluas $204.011 \mathrm{Ha}$ terdiri atas 110.877 Ha.

Perusahaan A merupakan perusahaan yang mengelola hutan produksi negara, termasuk dalam Divisi Regional Jawa Barat dan Banten terdiri dari: 14 Kesatuan Pemangkuan Hutan (KPH) ; 1 Kesatuan Bisnis Mandiri (KBM) Pemasaran; 1 KBM Industri Kayu Non Kayu; 1 KBM Agroforestry Ekologi dan Jasa Lingkungan (AEJ) serta 4 Seksi Perencanaan Hutan (SPH) ; seluas 678.244,6 Ha ("Pengelolaan Hutan", 2015). Dari 14 KHP tersebut, yang akan dikonversi menjadi karet terletak di 4 KPH, yaitu Sumedang, Majalengka, Purwakarta dan Indramayu (Susetyo, Ahmad, Widyasari, \& Syarifa, 2012).

\section{Perkebunan Karet di Jawa Barat}

Luas perkebunan karet di Jawa Barat dari tahun ke tahun semakin meningkat, seperti dijabarkan dalam Gambar 2. Pada tahun 2010 luasnya mencapai 55.762 Ha lalu terus meningkat hingga tahun 2014 menjadi 64.690 Ha. Kondisi tanaman berupa Tanaman menghasilkan (TM) 64,55\%, Tanaman Belum Menghasilkan (TBM) 22,88\% dan Tanaman Tidak Menghasilkan (TTM) $12,58 \%$,

Adapun kepemilikan kebun karet di Jawa Barat didominasi oleh perkebunan besar milik negara (Gambar 3).

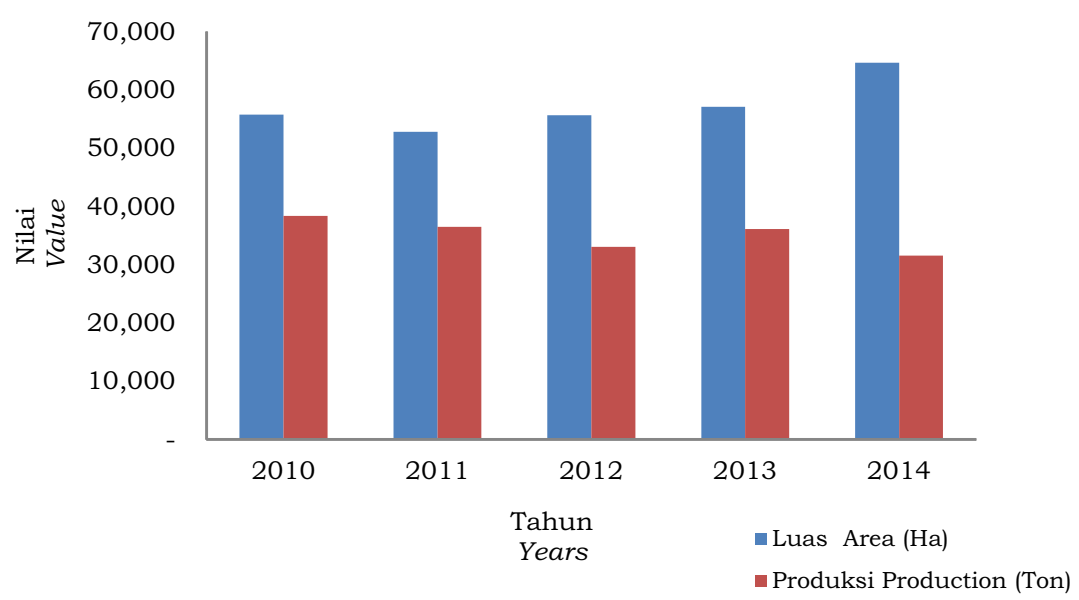

Gambar 2. Luas dan produksi karet di Jawa Barat, tahun 2010-2014

Figure 2. Area and production rubber at West Java, 2010-2014

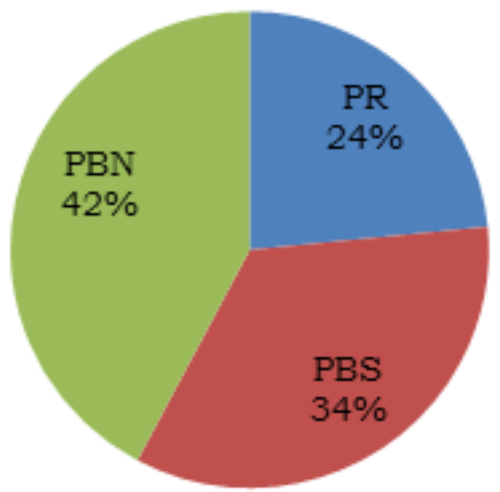

Keterangan (Remaks) :

$\mathrm{PBN}=$ Perkebunan besar milik negara (National estate)

$\mathrm{PR} \quad=$ Perkebunan rakyat (Smallholder)

$\mathrm{BS} \quad=$ Perkebunan besar milik swasta (Private estate)

Gambar 3. Proporsi luas kebun karet di Jawa Barat berdasarkan kepemilikannya, 2014

Figure 3. Proportion rubber plantation area at West Java by ownership, 2014 


\section{Infrastruktur dan Kelembagaan Masyarakat}

Pada umumnya infrastruktur di keempat kabupaten sudah memadai dengan tersedianya sarana pendidikan, kesehatan, perumahan, rumah ibadah, sarana air bersih, pasar dan lembaga ekonomi desa (Tabel 3). Kondisi infrastruktur transportasi pada calon lahan tanaman karet dapat ditempuh dengan sarana transportasi darat ke ibukota kecamatan dan ke ibukota kabupaten. Untuk Kabupaten Sumedang, Indramayu dan Majalengka memiliki akses jalan yang baik, sedangkan di Kabupaten Purwakarta memiliki kualitas jalan yang kurang baik (Gambar 4 dan 5).

\section{Land Use dan Vegetasi}

Perusahaan A sebagai perusahaan yang diberi mandat untuk mengelola hutan produksi di wilayah Jawa Barat dan Banten, berusaha meningkatkan produksi melalui diversifikasi produk. Pada tahun 2014, cukup banyak produk yang dihasilkan, baik berupa produksi kayu bulat (Tabel 4) dan produksi hasil hutan bukan kayu (Tabel 5).

Tabel 3. Jenis infrastruktur dan kelembagaan yang terdapat di desa-desa sekitar calon lahan karet

Table 3. Type of infrastructure and Institutional at villages around candidates rubber plantation

\begin{tabular}{|c|c|c|}
\hline & $\begin{array}{l}\text { Jenis infrastuktur dan } \\
\text { kelembagaan }\end{array}$ & $\begin{array}{c}\text { Rata-rata jumlah keberadaan infrastruktur } \\
\text { dan kelembagaan per desa }\end{array}$ \\
\hline No & $\begin{array}{c}\text { Type of infrastructure and } \\
\text { institutional }\end{array}$ & $\begin{array}{c}\text { The average number of infrastructure and } \\
\text { institutional per village }\end{array}$ \\
\hline 1 & Pendidikan & $\begin{array}{l}\text { SekolahDasar: } 3 \text { buah, tidak semua desa } \\
\text { memiliki SLTP dan SLTA }\end{array}$ \\
\hline 2 & Kesehatan & $\begin{array}{l}\text { Puskesmas pembantu: } 1 \text { unit, Paramedis: } \\
\text { 1orang }\end{array}$ \\
\hline 3 & Rumah ibadah & Masjid dan mushola : 9 buah \\
\hline 4 & Pemilikan sarana transportasi & $\begin{array}{l}\text { Pemilikan sepeda motor: } 87 \% \text { dari jumlah } \\
\text { rumah tangga } \\
\text { Pemilikan mobil: } 10 \% \text { dari jumlah rumah } \\
\text { tangga } \\
\text { Pemilikan truk angkutan : } 1 \% \text { dari jumlah } \\
\text { rumah tangga }\end{array}$ \\
\hline 5 & Penerangan listrik & $100 \%$ dari jumlah rumah tangga \\
\hline 6 & Sumber air bersih & $\begin{array}{l}\text { Sumur: } 20 \% \text {, sumber air: } 15 \% \text { dan PAM: } \\
65 \%\end{array}$ \\
\hline 7 & $\begin{array}{l}\text { Sumber bahan bakar minyak } \\
\text { dan gas }\end{array}$ & Depot eceran: 10 buah \\
\hline \multirow[t]{3}{*}{8} & Pasar tradisional & $0,3 \mathrm{bh}$ \\
\hline & Pasar kebutuhan pokok & Warung sembako: 30 buah \\
\hline & Pasar input pertanian & Toko pertanian : 0,2 buah \\
\hline 9 & $\begin{array}{l}\text { Pedagang pengumpul hasil } \\
\text { pertanian }\end{array}$ & 3 orang \\
\hline 10 & Lembaga petani & Kelompok tani: 6 buah, LMDH: 1 buah \\
\hline 11 & Lembaga ekonomi desa & koperasi : 1 buah, bank : 0,2, KUD : 1 \\
\hline 12 & Penyuluh pertanian & 1 orang \\
\hline
\end{tabular}

Sumber : data primer

Source : primary data 

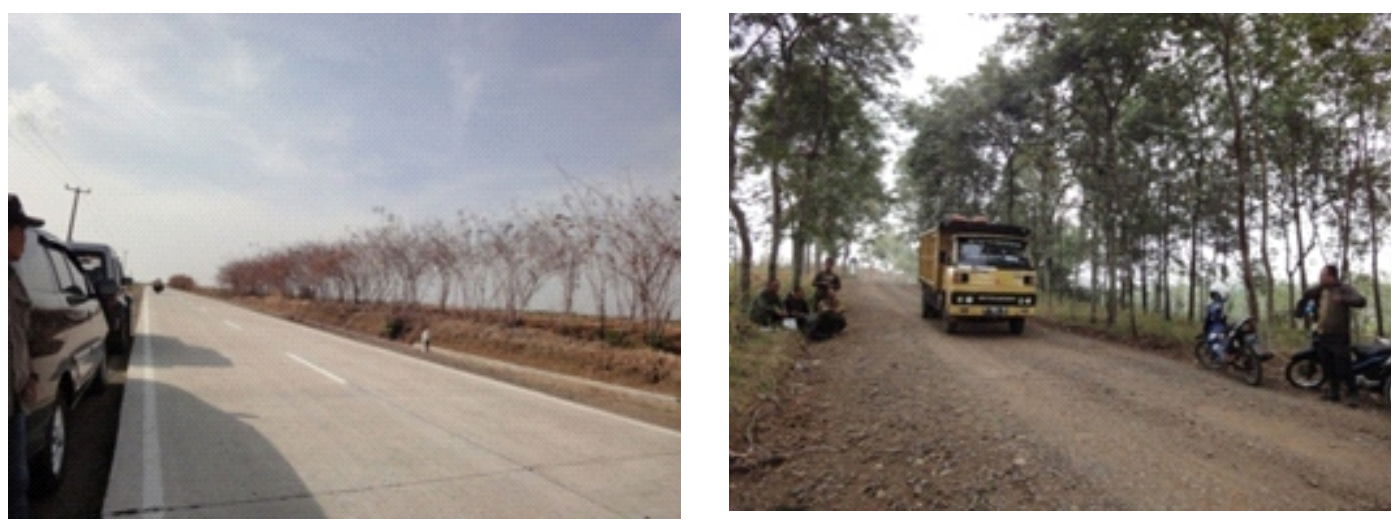

Gambar 4. Kondisi infrastruktur transportasi darat dinilai dapat digunakan untuk akses menuju ke calon lahan karet.

Figure 4. Conditions of land transport infrastructure that can be used for access to land of prospective rubber.

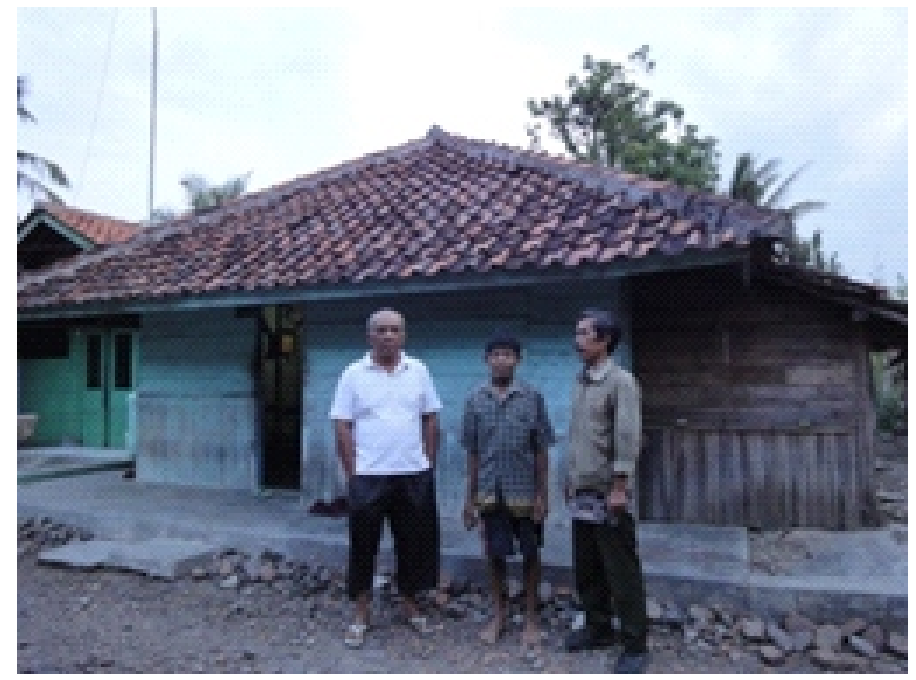

Gambar 5. Kondisi rumah pesanggem yang ada di Jawa Barat Figure 5. Conditions of pesanggem house at West Java

Tabel 4. Produksi kayu bulat (Jati, Pinus, Mahoni dan Sengon) menurut wilayah di Perusahaan A, 2014

Table 4. Production roundwood (Teak, Pine, Mahogany and Sengon) by region Company A, 2014

\begin{tabular}{ccccc}
\hline $\begin{array}{c}\text { Wilayah } \\
\text { Region }\end{array}$ & $\begin{array}{c}\text { Jati } \\
\text { Teak } \\
\left(\mathrm{m}^{3}\right)\end{array}$ & $\begin{array}{c}\text { Pinus } \\
\text { Pine } \\
\left(\mathrm{m}^{3}\right)\end{array}$ & $\begin{array}{c}\text { Mahoni } \\
\text { Mahogany } \\
\left(\mathrm{m}^{3}\right)\end{array}$ & $\begin{array}{c}\text { Sengon } \\
\text { Sengon } \\
\left(\mathrm{m}^{3}\right)\end{array}$ \\
\hline Sumedang & 3.111 & 2.050 & 70 & 192 \\
Majalengka & 19 & 45 & 128 & - \\
Purwakarta & 5.372 & 4.128 & 2.455 & 75 \\
Indramayu & 5.732 & - & 1.159 & - \\
$\begin{array}{c}\text { Jumlah } \\
\text { Total }\end{array}$ & 14.234 & 6.224 & 3.812 & 267 \\
\hline
\end{tabular}

Sumber (Source) : BPS, 2015 
Tabel 5. Produksi kayu bulat (Sonokeling, Puspa, Maesopsis, Accasia mangium, Rimba campur) menurut wilayah di Perusahaan A, 2014

Table 5. Production roundwood (Rosewood, Puspa, Maesopsis, Accasia mangium, mixed forest) by region at A Company, 2014

\begin{tabular}{cccccc}
\hline Wilayah & $\begin{array}{c}\text { Sonokeling } \\
\text { Rosewood } \\
\left(\mathrm{m}^{3}\right)\end{array}$ & $\begin{array}{c}\text { Puspa } \\
\text { Puspa } \\
\left(\mathrm{m}^{3}\right)\end{array}$ & $\begin{array}{c}\text { Maesopsis } \\
\text { Maesopsis } \\
\left(\mathrm{m}^{3}\right)\end{array}$ & $\begin{array}{c}\text { Accasiamangium } \\
\text { Accasiamangium } \\
\left(\mathrm{m}^{3}\right)\end{array}$ & $\begin{array}{c}\text { Rimba } \\
\text { campur } \\
\text { mixed forest } \\
\left(\mathrm{m}^{3}\right)\end{array}$ \\
\hline Sumedang & - & 2 & 27 & 3 & 74 \\
Majalengka & - & - & - & 284 & 216 \\
Purwakarta & 2 & - & - & 2.179 & 1.046 \\
$\begin{array}{c}\text { Indramayu } \\
\text { Jumlah }\end{array}$ & - & - & - & 13 & 23 \\
Total & 2 & 2 & 27 & 2.479 & 1.359 \\
\hline
\end{tabular}

Sumber (Source) : BPS, 2015

Pada tahun 2014, di antara empat wilayah, Indramayu menghasilkan kayu jati tertinggi, sedangkan untuk kayu lainnya wilayah Purwakarta menghasilkan kayu tertinggi untuk kayu Pinus, Mahoni, dan Accasia mangium.

Perusahaan A juga memproduksi hasil hutan bukan kayu berupa getah pinus, daun kayu putih, rumput Gajah, dan bambu seperti tertera dalam Tabel 6 .

Pengamatan di lapangan, beberapa tanaman hutan produksi juga dilakukan tumpangsari dengan tanaman semusim oleh para pesanggem. Pesanggem merupakan sebutan untuk petani yang ikut dalam kegiatan pengelolaan hutan di Jawa (Mahmud, 2015). Pesanggem mengerjakan lahan melalui PHBM (Pengelolaan Sumber Daya Hutan Bersama Masyarakat).
Pengelolaan PHBM adalah suatu sistem pengelolaan sumber daya hutan yang dilakukan bersama oleh Perusahaan A dan masyarakat desa hutan dan atau Perusahaan A dengan pihak lain yang berkepentingan (stakeholder) dengan jiwa berbagi, sehingga kepentingan bersama untuk mencapai keberlanjutan fungsi dan manfaat sumber daya hutan dapat diwujudkan secara optimal dan proporsional. PHBM dimaksudkan untuk memberikan arahan pengelolaan sumber daya hutan dengan memadukan aspekaspek ekonomi, ekologi, dan sosial secara proporsional dan profesional guna mencapai visi dan misi perusahaan. Nilai dan proporsi berbagi dalam PHBM ditetapkan sesuai dengan nilai dan proporsi masukan faktor produksi yang dikontribusikan oleh masingmasing pihak (perusahaan, masyarakat, desa hutan, pihak yang berkepentingan)

Tabel 6. Produksi hasil hutan bukan kayu di Perusahaan A, 2014

Table 6. Production of non wood forest product at Company A, 2014

\begin{tabular}{ccccc}
\hline $\begin{array}{c}\text { Wilayah } \\
\text { Region }\end{array}$ & $\begin{array}{c}\text { Getah pinus } \\
\text { Pinesap } \\
\text { (Ton) }\end{array}$ & $\begin{array}{c}\text { Daun kayu } \\
\text { putih } \\
\text { Eucalyptus } \\
\text { leaves } \\
\text { (Ton) }\end{array}$ & $\begin{array}{c}\text { Rumput Gajah } \\
\text { Bulrush } \\
\text { (Ton) }\end{array}$ & $\begin{array}{c}\text { Bambu } \\
\text { Bamboo } \\
\text { (Batang) }\end{array}$ \\
\hline Sumedang & 1.461 & 56 & 34 & 400 \\
Majalengka & 384 & 2.367 & 150 & - \\
Purwakarta & 415 & 670 & - & 46.375 \\
$\begin{array}{c}\text { Indramayu } \\
\text { Jumlah }\end{array}$ & - & 10.909 & - & - \\
Total & 2.260 & 14.002 & 184 & 46.775 \\
\hline
\end{tabular}

Sumber (Source) : BPS, 2015 
sebagaimana ditetapkan dalam Surat Keputusan Direksi Perusahaan A pada Tahun 2009.

PHBM dilaksanakan berdasarkan kesepakatan antara Perusahaan A dan LMDH. Dalam kontrak, tercantum lahan yang dialokasikan di hutan negara yang dibagikan kepada pesanggem, yang mengelola lahan melalui kerjasama diantara mereka. Umumnya, jenis tanaman dipilih berdasarkan petak dan kelompok tani hutan yang dikelola oleh pesanggem. Alokasi lahan biasanya dikelola oleh pesanggem secara individu (Gambar 6).

Pada saat pengamatan di lapangan, kpegiatan PHBM yang tampak adalah kegiatan tumpangsari di antara tanaman kayu seperti Gambar 7. Di sela tanaman kayu, dilakukan penanaman tanaman semusim yaitu singkong, padi gogo, kacang ijo, kacang panjang, timun, semangka, jagung, dan pisang. Dengan variasi tanaman tumpang sari tersebut, dapat diperoleh pendapatan sekitar IDR 10 - 40 juta per tahun atau setara dengan IDR 833 ribu 3,75 juta per bulan. Besarnya pendapatan tersebut sudah setara bahkan melebihi UMK (Upah Minimum Kabupaten di Jawa Barat) yang tertera dalam Tabel 7. Meskipun demikian, bilamana terjadi kenaikan upah hingga $84 \%$, secara finansial pembangunan kebun karet tetap layak untuk dilaksanakan

Jika hutan produksi menjadi kebun karet, kegiatan tumpangsari tanaman semusim hanya dapat dilakukan pada saat tanaman karet berusia 0 sampai 3 tahun saja, karena selanjutnya gawangan akan tertutup oleh kanopi pohon karet.

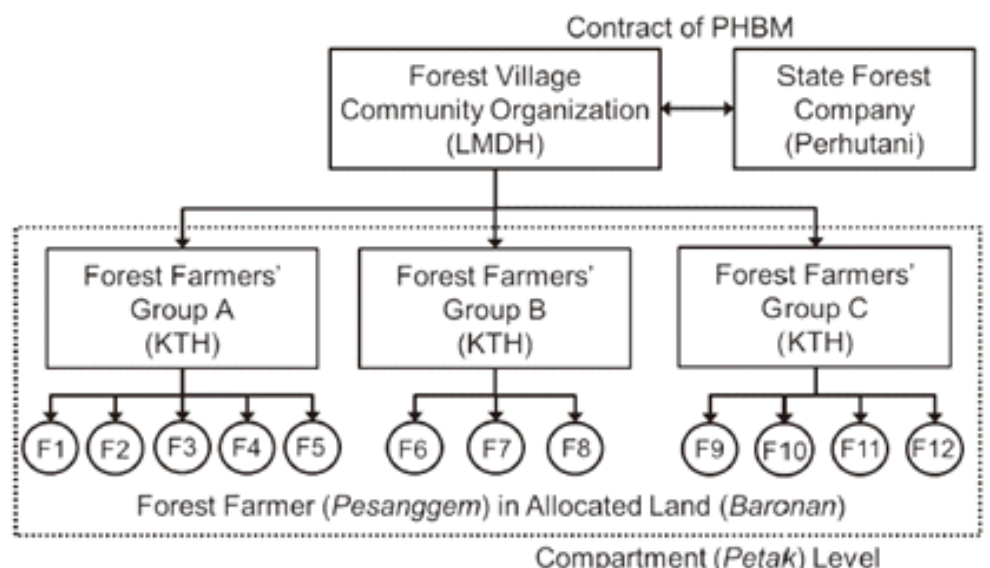

Gambar 6. Struktur pelaksanaan PHBM Figure 6. Structure of PHBM implementation

Sumber (Source) : Fujiwara et al., 2012
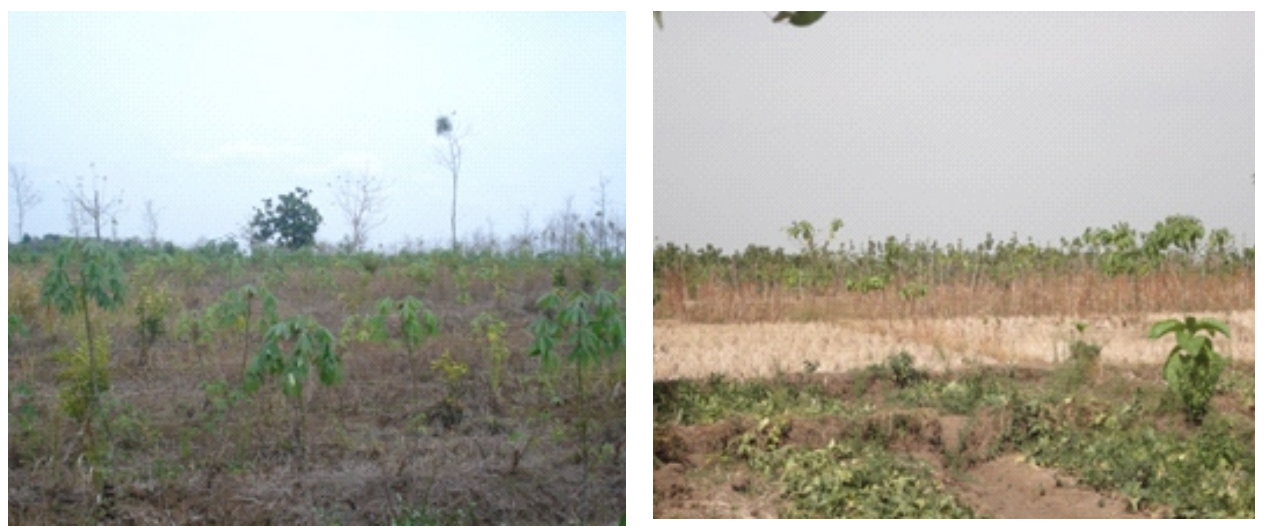

Gambar 7. Kondisi tumpang sari tanaman semusim dengan tanaman kayu Figure 7. Conditions of intercropping annuals with timber plants 
Tabel 7. Besaran Upah Minimum Kabupaten di Jawa Barat tahun 2014-2015 Table 7. Value of District Minimum Wages at West Java, 2014-2015

\begin{tabular}{lcc}
\hline & \multicolumn{2}{c}{$\begin{array}{c}\text { UMK } \\
\text { Kabupaten } \\
\text { District }\end{array}$} \\
\cline { 2 - 3 } & \multicolumn{2}{c}{$\begin{array}{c}\text { District Minimum } \text { Wages } \\
\text { (IDR/month) }\end{array}$} \\
\hline Sumedang & 2014 & 2015 \\
Majalengka & 1.735 .473 & 2.001 .195 \\
Purwakarta & 1.000 .000 & 1.245 .000 \\
Indramayu & 2.100 .000 & 2.600 .000 \\
\hline
\end{tabular}

Sumber: Surat Keputusan Gubernur Jawa Barat, 2014

Source: Decree of West Java Govenor, 2014

Selain tanaman semusim, juga ditemukan sapi dan kerbau berkeliaran di hutan produksi. Hal tersebut sudah menjadi kebiasaan masyarakat sekitar karena mereka mencari rumput sebagai pakan ternaknya (Gambar 8). Kebiasaan tersebut, akan mengganggu kulit pohon karet bilamana wilayah tersebut akan dikonversi menjadi karet. Pemilik ternak harus mengandangkan ternaknya di wilayah tertentu sehingga kebun karet tidak terganggu.

\section{Penduduk dan Mata Pencaharian}

Jumlah penduduk terbanyak di Desa Sanca, Kabupaten Indramayu, lebih dari 90\% penduduk merupakan penduduk lokal suku Sunda dan beragama Islam, sangat jarang ada pendatang dari daerah lain (Tabel 8 dan Tabel 9).
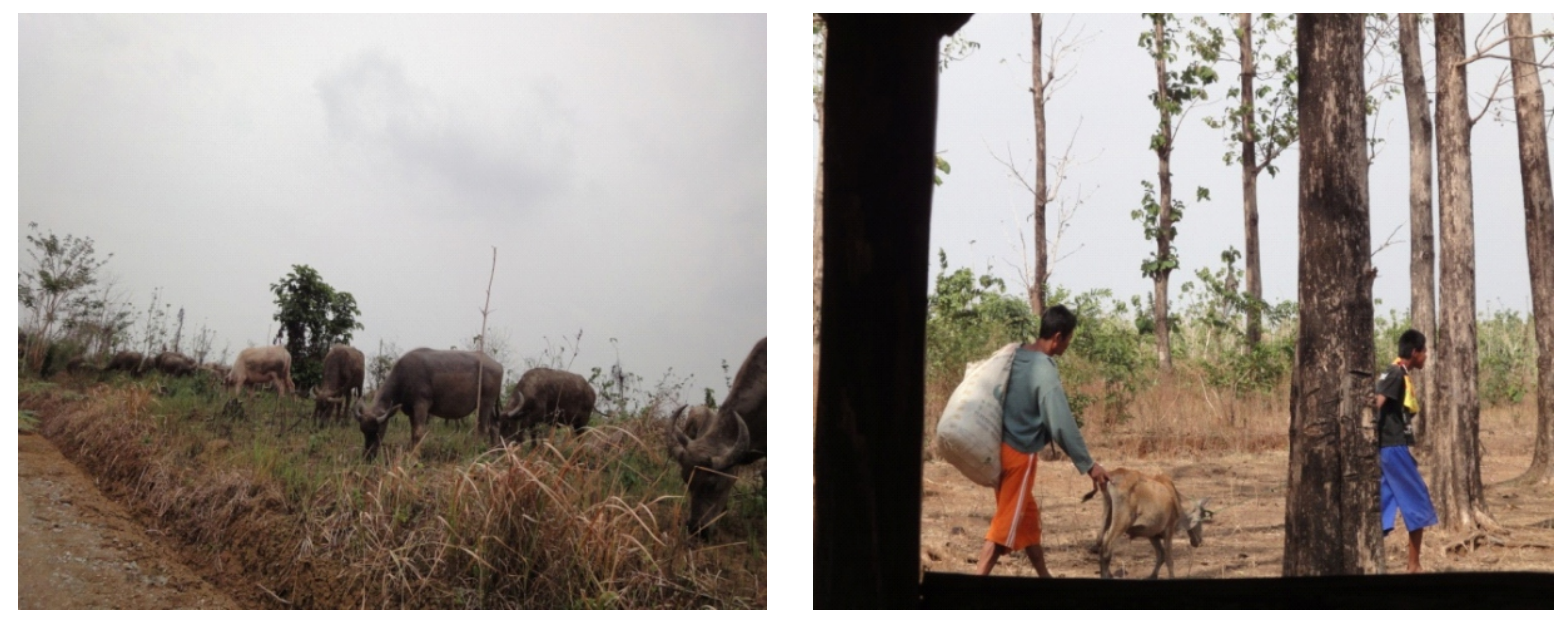

Gambar 8. Ternak sapi dan kerbau yang berkeliaran di kawasan hutan Figure 8. Cattle and buffaloes that roam in the forest area 
Tabel 8. Karakteristik demografi desa-desa sekitar calon kebun karet di Kabupaten Sumedang dan Majalengka

Table 8. Demographic characteristics of villages surrounding prospective rubber area at Sumedang and Majalengka districts

\begin{tabular}{|c|c|c|c|c|c|}
\hline \multirow{3}{*}{$\begin{array}{l}\text { Uraian } \\
\text { Description }\end{array}$} & \multicolumn{4}{|c|}{$\begin{array}{l}\text { Kabupaten Sumedang } \\
\text { Sumedang district }\end{array}$} & \multirow{3}{*}{$\begin{array}{c}\text { Kabupaten } \\
\text { Majalengka } \\
\text { Majalengka } \\
\text { district } \\
\text { Kecamatan } \\
\text { Kertajati } \\
\text { Kertajati } \\
\text { sub-district } \\
\\
\text { Desa } \\
\text { Mekarmulya } \\
\text { Mekarmulya } \\
\text { village }\end{array}$} \\
\hline & \multicolumn{2}{|c|}{$\begin{array}{l}\text { Kecamatan Tomo } \\
\text { Tomo sub-district }\end{array}$} & \multicolumn{2}{|c|}{$\begin{array}{c}\text { Kecamatan } \\
\text { Ujung Jaya } \\
\text { Ujung Jaya sub-district }\end{array}$} & \\
\hline & $\begin{array}{c}\text { Desa Tomo } \\
\text { Tomo } \\
\text { village }\end{array}$ & $\begin{array}{l}\text { Desa } \\
\text { Karyamukti } \\
\text { Karyamukti } \\
\text { village }\end{array}$ & $\begin{array}{c}\text { Desa } \\
\text { Ujung } \\
\text { Jaya } \\
\text { Ujung } \\
\text { Jaya } \\
\text { village }\end{array}$ & $\begin{array}{c}\text { Desa } \\
\text { Sakur } \\
\text { Jaya } \\
\text { Sakur } \\
\text { Jaya } \\
\text { village }\end{array}$ & \\
\hline Jumlah penduduk (KK) & 1.240 & 680 & 2.546 & 1.035 & 1.000 \\
\hline Jumlah jiwa (orang) & 3.475 & 2.017 & 6.234 & 1.035 & 3.000 \\
\hline $\begin{array}{l}\text { Jumlah anggota } \\
\text { keluarga (orang) }\end{array}$ & 3 & 3 & 2 & 1 & 3 \\
\hline Luas desa $\left(\mathrm{Km}^{2}\right)$ & 869 & 642 & 340 & 1.031 & 200 \\
\hline $\begin{array}{l}\text { Kerapatan penduduk } \\
\text { (orang } / \mathrm{km}^{2} \text { ) }\end{array}$ & 4 & 3 & 18 & 1 & 15 \\
\hline Usia produktif (\%) & 72 & 68 & 60 & 63 & 70 \\
\hline \multicolumn{6}{|l|}{ Asal Suku } \\
\hline * Lokal (Sunda) (\%) & 95 & 95 & 95 & 90 & 90 \\
\hline $\begin{array}{l}\text { * Pendatang daerah } \\
\text { lain (\%) }\end{array}$ & 5 & 5 & 5 & 10 & 10 \\
\hline \multicolumn{6}{|l|}{ Agama dan kepercayaan } \\
\hline * Islam (\%) & 98 & 98 & 98 & 98 & 98 \\
\hline * selain islam (\%) & 2 & 2 & 2 & 2 & 2 \\
\hline
\end{tabular}

Sumber: Data monografi desa

Source : Data monograph of village 
Tabe19. Karakteristik demografi desa-desa sekitar calon lahan karet di Kabupaten Purwakarta dan Indramayu

Table 9. Demographic characteristics of villages surrounding prospective rubber area at Purwakarta district and Indramayu districts

\begin{tabular}{|c|c|c|c|c|}
\hline \multirow{3}{*}{$\begin{array}{l}\text { Uraian } \\
\text { Description }\end{array}$} & \multirow{2}{*}{$\begin{array}{c}\text { Kabupaten } \\
\text { Purwakarta } \\
\text { Purwakarta } \\
\text { district } \\
\text { Kecamatan } \\
\text { Kiarapedes } \\
\text { Kiarapedes } \\
\text { sub-district } \\
\end{array}$} & \multicolumn{3}{|c|}{$\begin{array}{l}\text { Kabupaten Indramayu } \\
\text { Indramayu district }\end{array}$} \\
\hline & & $\begin{array}{c}\text { Kecamatan } \\
\text { Terisi } \\
\text { Terisi sub- } \\
\text { district } \\
\end{array}$ & $\begin{array}{l}\text { Kecamatar } \\
\text { Gantar su }\end{array}$ & $\begin{array}{l}\text { Gantar } \\
\text {-district }\end{array}$ \\
\hline & $\begin{array}{c}\text { Desa } \\
\text { Margaluyu } \\
\text { Margaluyu } \\
\text { village } \\
\end{array}$ & $\begin{array}{c}\text { Desa } \\
\text { Cikawung } \\
\text { Cikawung } \\
\text { village } \\
\end{array}$ & $\begin{array}{c}\text { Desa } \\
\text { Mekarwaru } \\
\text { Mekarwaru } \\
\text { village }\end{array}$ & $\begin{array}{c}\text { Desa Sanca } \\
\text { Sanca } \\
\text { village }\end{array}$ \\
\hline Jumlah penduduk (KK) & 3.000 & 2.047 & 2.061 & 2.145 \\
\hline $\begin{array}{l}\text { Jumlah jiwa (orang) } \\
\text { Jumlah anggota keluarga }\end{array}$ & 5.000 & 5.600 & 4.900 & 7.074 \\
\hline (orang) & 2 & 3 & 2 & 3 \\
\hline Luas desa $\left(\mathrm{Km}^{2}\right)$ & 1.300 & 7.400 & 4.300 & 6.095 \\
\hline $\begin{array}{l}\text { Kerapatan penduduk } \\
\text { (orang/ } \mathrm{km}^{2} \text { ) } \\
\text { Usia produktif (\%) }\end{array}$ & $\begin{array}{r}4 \\
70\end{array}$ & $\begin{array}{r}1 \\
60\end{array}$ & $\begin{array}{r}1 \\
70\end{array}$ & $\begin{array}{r}1 \\
80\end{array}$ \\
\hline Asal Suku & & & & \\
\hline * Lokal (Sunda) (\%) & 90 & 90 & 99 & 99 \\
\hline $\begin{array}{l}\text { * Pendatang daerah lain } \\
(\%) \\
\text { Agama dan kepercayaan }\end{array}$ & 10 & 10 & 1 & 1 \\
\hline * Islam (\%) & 98 & 98 & 98 & 98 \\
\hline${ }^{*}$ selain islam (\%) & 2 & 2 & 2 & 2 \\
\hline
\end{tabular}

Sumber: Data monografi desa

Source: $\quad$ Data of village monograph 
Tabel 10. Persentase sumber mata pencaharian penduduk desa-desa sekitar calon lahan karet di Kabupaten Sumedang dan Majalengka

Table 10. Percentage of population livelihood villages surrounding the propective rubber land at Sumedang district and Majalengka district

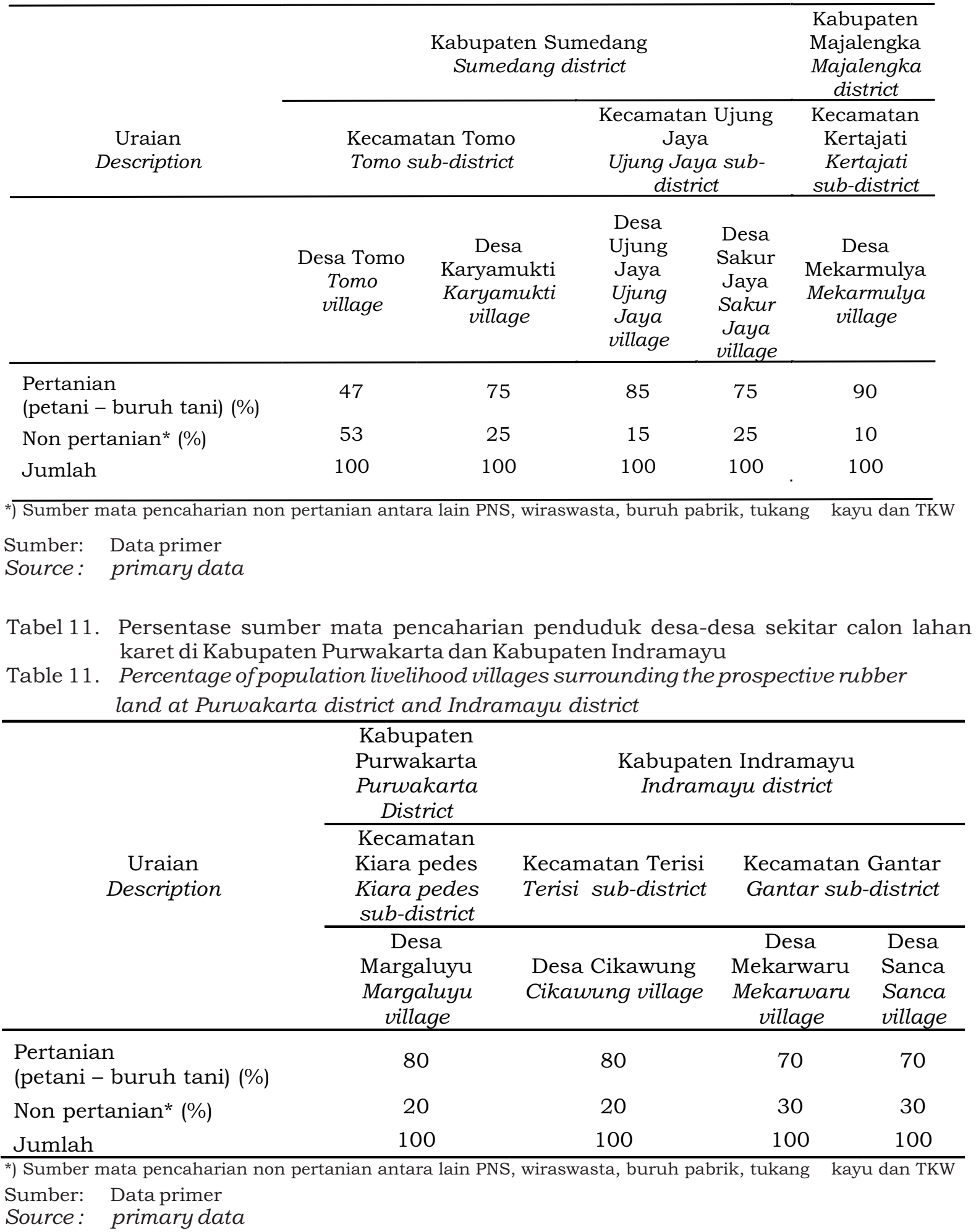




\section{Respon Masyarakat terhadap Pembangunan Kebun Karet}

Para responden umumnya belum mengetahui teknis budidaya tanaman karet, sehingga bilamana mereka ditarik menjadi tenaga kerja di Perusahaan A, maka harus dibekali ilmu pengetahuan teknis budidaya tanaman karet.

Berikut hasil survei respon masyarakat mengenai rencana pengembangan kebun karet di hutan produksi :

1. Kabupaten Sumedang

Pada umumnya responden menerima hadirnya rencana pembangunan perkebunan karet, karena akan membuka lapangan kerja yang luas, dan diharapkan perekrutan tenaga berasal dari pesanggem yang telah mengikuti PHBM. Di sisi lain, para pesanggem yang terikat dalam PHBM tanaman kayu khawatir akan ada perubahan bentuk kerjasama, apakah dilanjutkan atau diberhentikan dan juga pola tumpangsari karena akan merubah pola kerja mereka. Di Kabupaten Sumedang, potensi tenaga kerja cukup banyak dengan dominasi tenaga kerja sebagai petani, sehingga diharapkan akan memudahkan untuk mengajak mereka sebagai tenaga kerja di kebun karet bilamana hutan produksi sudah dikonversi menjadi kebun karet.

2. Kabupaten Majalengka

Pada umumnya merespon positif dengan konversi hutan produksi menjadi kebun karet, namun diharapkan tetap menggunakan sistem kerjasama PHBM yaitu bagi hasil kayu dan non kayu, bukan konsep perkebunan (hubungan pemilik perusahaan dan karyawan saja).

3. Kabupaten Purwakarta

Para responden secara umum setuju dengan pengembangan tanaman karet, karena diharapkan terbentuk lapangan kerja baru dan menambah pendapatan. Di Kabupaten Purwakarta, pekerja yang menjadi pesanggem hanya sedikit, sebagian besar menjadi buruh tenaga harian lepas bagi perusahaan $\mathrm{A}$, dan mengolah lahan milik pribadi. Kondisi
Kabupaten Purwakarta berbeda dengan kabupaten lainnya, dimana ketersediaan tenaga kerja untuk pertanian sedikit karena bersaing dengan industri terutama dalam hal upah. Sebagian besar tenaga yang tersedia berusia di atas 35 tahun, jika perusahaan A ingin membangun kebun karet memerlukan tenaga kerja tambahan dari luar wilayah. Selain itu, lokasi lahan yang berbukit akan memerlukan spesifikasi teknis yang khusus, dan biaya ekstra dibanding lahan datar.

4. Kabupaten Indramayu

Respon masyarakat Kabupaten Indramayu hampir sama dengan kabupaten lainnya terutama dalam hal pola kerjasama yang akan diterapkan jika dikonversi menjadi kebun karet. Jika pengelolaan kebun karet dibuat sistem perkebunan (perusahaantenaga kerja) bukan bentuk bagi hasil seperti konsep PHBM sebelumnya, maka mereka merasa khawatir terganggunya pola kerja dan pola tumpangsari yang sudah ada. Terutama tumpangsari tanaman kayupadi, yang merupakan bahan makanan pokok.

Secara umum, respon masyarakat terhadap pengembangan kebun karet di hutan produksi mengalami kekhawatiran akan adanya perubahan PHBM yang sudah berlangsung lama. Masyarakat perlu diberi pemahaman bahwa kebun karet merupakan tanaman tahunan yang dipanen sejak usia 6 tahun, dan disadap tiga hari sekali, tentunya memerlukan tenaga kerja yang banyak dan aktivitas kebun yang banyak mulai dari persiapan lahan hingga pemanenan. Sangat berbeda dengan pengelolaan hutan produksi (tanaman kayu) yang teknis budidayanya hanya di waktu-waktu tertentu. Jumlah tenaga kerja penyadap yang diperlukan bagi perkebunan karet cukup banyak, tergantung pada sistem eksploitasi yang akan digunakan dapat dilihat dalam Tabel 12 .

Pendekatan kelembagaan baik secara formal maupun informal antara perusahaan dengan aparat desa dan masyarakat sekitar, terutama para pesanggem yang berkaitan langsung dengan 
proyek pembangunan kebun karet sangat penting dilaksanakan untuk keberlangsungan pembangunan kebun karet ke depannya dan tidak terjadi konflik, karena apabila terjadi konflik kehutanan akan membawa malapetaka bagi pihak yang terlibat atau pihak lain yang tidak terlibat langsung. Individu-individu tertentu mendapat ancaman dan sumber daya alam menjadi rusak. Pengelolaan konflik diperlukan untuk mengantisipasi konflik dan menghindari atau menguranginya serta meningkatkan keterbukaan dalam menyikapi perbedaan penilaian. Penyebab umum konflik di sektor kehutanan antara lain kegiatan HPH, aktivitas penebangan liar (illegal logging), penetapan kawasan lindung dan penetapan kawasan taman nasional, pembangunan HTI dan perkebunan kelapa sawit. Konflik ini terjadi karena perbedaan pandangan mengenai hak atas lahan, pelanggaran perjanjian oleh pihak-pihak yang terkait maupun ketidakjelasan batas kawasan (Wulan, Yasmi, Purba, \& Wollenberg, 2004).

Tabel 12. Kebutuhan jumlah tenaga kerja penyadap per unit pembangunan kebun karet

Table 12. Number of rubber tappers which are needed for every unit of rubber plantation development

\begin{tabular}{|c|c|c|}
\hline \multirow[t]{2}{*}{$\begin{array}{l}\text { Sistem sadap } \\
\text { Tapping system }\end{array}$} & \multicolumn{2}{|c|}{$\begin{array}{c}\text { Kebutuhan jumlah tenaga kerja penyadap } \\
\text { (orang) } \\
\text { Number of rubber tappers needed } \\
\text { (person) }\end{array}$} \\
\hline & Per Ha & Per $3000 \mathrm{Ha}$ \\
\hline $\mathrm{S} / 2 \mathrm{D} / 2$ & 0,50 & 1.500 \\
\hline $\mathrm{S} / 2 \mathrm{D} / 3$ & 0,33 & 900 \\
\hline $\mathrm{S} / 2 \mathrm{D} / 4$ & 0,25 & 750 \\
\hline
\end{tabular}

\section{KESIMPULAN}

Perencanaan pembangunan kebun karet sebaiknya ditinjau dari sisi agroklimat, ekonomi dan sosial. Dari kajian yang sudah dilakukan, secara finansial dan agroklimat sudah layak untuk dilaksanakan. Dalam tulisan ini, kondisi sosial dijabarkan berdasarkan data monografi tingkat kabupaten dan respon masyarakat terhadap pembangunan kebun karet di wilayahnya. Karakteristik masyarakat sekitar hutan produksi yang terletak di Kabupaten Sumedang, Majalengka, Purwakarta dan Indramayu dapat disimpulkan sebagai berikut : kondisi umum kabupaten telah memiliki infrastruktur dan kelembagaan yang memadai, tenaga kerja tersedia yang didominasi dengan mata pencaharian di bidang pertanian, penduduk asli Sunda, dan beragama Islam. Land use dan vegetasi di hutan produksi berupa tanaman Jati, Kayu
Putih, Mahoni dan Gmelina, tanaman tumpang sari serta ternak sapi dan kerbau. Jika sebagian hutan produksi dikonversi menjadi perkebunan karet, pada umumnya memiliki respon setuju namun perlu meninjau ulang konsep PHBM yang sudah berjalan. Masyarakat sangat tergantung pada kegiatan PHBM, salah satunya dengan melakukan tumpangsari tanaman semusim di antara tanaman kayu yang mampu menghasilkan pendapatan melebihi UMK. Telah berkembangnya ternak sapi dan kerbau yang bebas berkeliaran di areal calon kebun karet cukup mengganggu bilamana sudah menjadi kebun karet. Dari 4 kabupaten yang yang dianalisis, kabupaten Purwakarta akan kurang prospektif untuk dikembangkan komoditas karet karena keterbatasan tenaga kerja dan terjadi persaingan dengan perusahaan industri yang sudah banyak berkembang. 
Saran yang sebaiknya dilakukan adalah perlunya sosialisasi yang tepat dan terpadu perihal konsep PHBM kepada masyarakat yang terlibat dalam PHBM dan masyarakat sekitar, agar perkebunan karet nantinya dapat dibangun berkelanjutan. Melibatkan mereka sebagai tenaga kerja di perkebunan juga penting dilakukan, dengan upah yang layak. Perihal ternak sapi dan kerbau, sebaiknya dibangun kerjasama membangun kandang ternak, dan pakan ternak berupa rumput gajah dapat ditanam di kawasan hutan produksi. Kerjasama kotoran ternak sebagai pupuk bagi kebun karet dan pakan ternak dapat menjadi salah satu sarana mempererat hubungan masyarakat dengan Perusahaan A. Dengan kerjasama yang saling menguntungkan, diharapkan ke depannya dapat meminimalisir konflik antar kepentingan.

\section{DAFTAR PUSTAKA}

Arief, A. (2001). Hutan dan kehutanan. Yogyakarta, Indonesia: Kanisius.

Badan Pusat Statistik. (2014). Jawa Barat dalam Angka 2014. Bandung, Indonesia: Badan Pusat Statistik [BPS] Provinsi Jawa Barat.

Badan Pusat Statistik. (2015). Jawa Barat dalam Angka 2015. Bandung, Indonesia: Badan Pusat Statistik [BPS] Provinsi Jawa Barat.

Chantuma, A., Kunarasiri, A., \& Chantuma, P. (2012). Rubber new planting in Thailand: towards the world affected on climate change. Rubber Thai Journal, 1, 40-47.

Fujiwara, T., Septiana, R. M., Awang, S. A., Widayanti, W. T., Bariatul, H., Hyakumura, K., \& Sato, N. (2012). Changes in local social economy and forest management through the introduction of collaborative forest management (PHBM), and the challenges it poses on equitable partnership: A case study of KPH Pemalang, Central Java, Indonesia. TROPICS, 20(4), 115-134. Doi: $10.3759 /$ tropics.20.115
International Rubber Study Group. (2015). Statistical summary of world rubber situation. Singapore, Singapore: IRSG.

Kaban, M. S. (2009). Kebijakan pengembangan kayu karet melalui hutan tanaman rakyat. Prosiding Lokakarya Nasional Pemuliaan Tanaman Karet 2009 (pp 2-5). Batam, Indonesia: Pusat Penelitian Karet.

Gubernur Jawa Barat. (2013). Keputusan Gubernur Jawa Barat Nomor: 561/Kep.1636-Bangsos/2013 tentang Upah Minimum Kabupaten/Kota di Jawa Barat tahun 2014. Bandung, Indonesia: Gubernur Jawa Barat.

Gubernur Jawa Barat. (2014). Keputusan Gubernur Jawa Barat Nomor: 561/Kep.1581-Bangsos/2014 tentang Upah Minimum Kabupaten/Kota di Jawa Barat tahun 2015. Bandung, Indonesia: Gubernur Jawa Barat.

Mahmud, M. (2015). Gender dan kehutanan masyarakat. Yogyakarta, Indonesia: Deepublish.

Muschett. (1977). Sustainable development. Kuliah manajemen pembangunan wilayah dan kota. Semarang, Indonesia: Universitas Diponegoro.

Nugroho, P. A. (2012). Potensi pengembangan karet melalui pengusahaan hutan tanaman industri. Warta Perkaretan, 31(2), 95-102.

Pengelolaan hutan mengalami redesain. (2012, 13 Agustus). Pikiran Rakyat. Diakses dari http://www.bumn.go.id

Pusat Penelitian Karet. (2015). Studi kelayakan pembangunan kebun karet di wilayah Perusahaan A Divisi Regional Jawa Barat dan Banten. Bogor, Indonesia: Pusat Penelitian Karet.

Simon, H. (1993). Hutan Jati dan Kemakmuran. Yogyakarta, Indonesia: Aditya Media. 
Widyasari

Syarifa, L. F. (2014). Studi kelayakan investasi pembangunan perkebunan karet di Sumatera Selatan. Jurnal Penelitian Karet, 32(2), 148-156. 